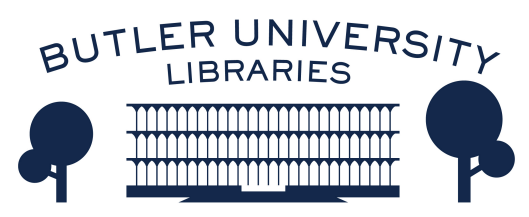

Journal of Hindu-Christian Studies

Volume 3

Article 6

January 1990

\title{
Book Review: "Hindu-Christian Dialogue: Perspectives and Encounters"
}

John B. Carman

Follow this and additional works at: https://digitalcommons.butler.edu/jhcs

Part of the Religion Commons

\section{Recommended Citation}

Carman, John B. (1990) "Book Review: "Hindu-Christian Dialogue: Perspectives and Encounters"," Journal of Hindu-Christian Studies: Vol. 3, Article 6.

Available at: https://doi.org/10.7825/2164-6279.1029

The Journal of Hindu-Christian Studies is a publication of the Society for Hindu-Christian Studies. The digital version is made available by Digital Commons @ Butler University. For questions about the Journal or the Society, please contact cbauman@butler.edu. For more information about Digital Commons @ Butler University, please contact digitalscholarship@butler.edu. 


\section{BOOK REVIEWS}

Hindu-Christian Dialogue: Perspectives and Encounters. Dr. Harold Coward, ed., Faith Meets Faith Series, Maryknoll: Orbis Books, xix + 281p., \$45.45 (cloth); \$19.45 (paper).

Harold Coward has edited an informative and thought-provoking survey of many aspects of Hindu-Christian interaction that are pertinent for contemporary dialogue between Hindus and Christians and for reflection on the problems and prospects of all inter-religious dialogue. This is not the "state-of-the-art assessment of Hindu-Christian Dialogue" that he promises (p. 7), but what the book does accomplish is more important than what was promised. While Dr. Coward does not himself define dialogue, the way he has organized the volume suggests that he has a very broad understanding of the concept, one that includes what others might prefer to call interaction or encounter. Perhaps the volume's subtitle, Perspectives and Encounters, suggests the content more clearly than the title.

The Foreword, Introduction, and eighteen chapters all touch on one or more of the following four topics: 1) socio-religious interaction among Hindus and Christians; 2) what might be called "long-distance dialogue," i.e., the mutual responses of Hindus and Christians to one another's beliefs and practices, 3 ) dialogue in the stricter sense as face-to-face conversation, especially more formally organized conversation, and 4) theoretical reflection on the nature of dialogue and its relation to wider dimensions of Hindu-Christian encounter, as well as to Hindu and Christian theology and to the academic study of religion.

The range of interactions presented is impressive, including two chapters on the history of Hindu-Christian relations in Kerala by Anand Amaladass and Roland E. Miller, Paul Younger's chapter on three special forms of Christian worship in South India in which Hindus participate, and historical surveys of the encounters in Europe, Canada, and Trinidad by Eric J. Sharpe, David J. Goa, and Anantanand Rambachan, respectively. Mutual influences are traced in many of those articles and are the more specific subject of treatments of nineteenth and twentieth century Hindu reformers in India (cf. chapters on "The Response of the Hindu Renaissance to Christianity" and "Hindu Views of Christ" by Ronald Neufeldt, and a chapter on "Gandhi and the Christians" by John C. B. Webster). In addition Steven J. Gelberg has brought in one phase of the encounter in the United States in his chapter on Swami Bhakti Vedanta and the International Society for Krishna Consciousness. There is also Murray Rogers' statement of his personal experience of Hindu spirituality. Because of his ongoing involvement in face-to-face dialogue, this is also a contribution to the third topic, which, despite the title of the book, is treated directly only in David Goa's report on the Canadian situation and in the late Richard W. Taylor's pessimistic critique of the paucity of current dialogue in India.

There are far more articles in which some definition of dialogue or other reflection on the nature of dialogue appears. These definitions are clustered around two rather different positions. The first is eloquently stated by Raimundo Panikkar in his Foreword and is restated with some modifications by Klaus Klostermaier in the 


\section{Book Reviews}

final chapter on "The Future of Hindu-Christian Dialogue," as well as by Murray Rogers and S. Wesley Ariarajah ("A World Council of Churches' Perspective").

Raimundo Panikkar proposes in his Foreword that Hindu-Christian dialogue "changes not only our opinion of the religion we study and dialogue with, it also changes our stand and interpretation of our own religion" (p. xiv). Since "both religions are on the brink of a mutation" with "a re-interpretation of tradition and a reformulation of the main tenets of both religions,... [t]his puts the dialogue in a very peculiar and fruitful position."

I am not saying that dogmas do not exist. I am affirming that dogmatism is not needed, and that even dogmas are on the move. Saying this, I am at the same time uncovering for the dialogue a task beyond the already important tasks of understanding each other or dispelling misunderstanding. I am ascribing to the dialogue the important role of building a new self-understanding of both traditions. (p. xv)

Some of the contributions, however, have a broader or less ambitious view of dialogue. Eric Sharpe criticizes liberal enthusiasts of dialogue for assuming that they are in a position to speak for and even to revise the entire Christian or Hindu tradition (p. 112). The "understanding" that Dr. Panikkar regards as a past or preliminary stage is seen by Ronald Neufeldt as the essential purpose of dialogue.

I do not accept the all-too-frequent understanding of dialogue, that is, discussion for the sake of finding points of agreement under the assumption that it is the points of agreement that tell us what the various religions are really about. Such an assumption makes a mockery of religious discourse and is not necessary for dialogue to take place. Indeed, in dialogue there should be the possibility for a fair bit of disagreement as well as agreement. The issue in dialogue is not agreement or disagreement, but an attitude of openness and seeing the other as significant in the exchange of ideas and the argumentation that is aimed at understanding and allows for the possibility of both education and change. (p. 42)

Dialogue's goal of understanding "separates dialogue from polemic, the goal of which is denunciation of the opposing position, and apologetic, the goal of which is defense of one's own position." (p. 42)

Even such polemic and apologetic, however, is treated as a kind of premodern dialogue by F. Richard Young in his fascinating reconstruction of the encounter in 1543 between Francis Xavier and Saivite Brahmins at the Tiruchendur Temple near the southern tip of India. Richard Young maintains that each phase in that encounter "reveal[s] features that are symptomatic of Hindu-Christian dialogue" (p. 65). At one point Xavier broke off the discussion and "imperiously signalling the brahmins to seat themselves, he began to recite in Tamil the Apostles' Creed, Decalogue and a sermon..." (p. 71). This, as Dr. Young notes, "violates every sine qua non of interreligious dialogue as contemporarily understood and yet may have been precisely what had to happen before the Tiruchendur brahmins could acknowledge that Xavier was a deeply religious individual" (p. 71). Xavier reports 
that when he finished the Brahmins applauded him. Why? "Despite mispronunciation and mistranslation. .. it was evident that he believed in something fervently and was ardently trying to tell them what it was. This underlines the importance of the 'human nexus' in dialogue... Somehow Xavier's ardor did stir them" (p. 71-72). Dr. Young is certainly not proposing Francis Xavier as a model for contemporary dialogue, but he has quite skillfully suggested the importance of Christian fervor in persuading Saivite Brahmins that Christians were religious people worthy even of being engaged in discussion.

A number of the articles raise issues, either explicitly or implicitly, that deserve much greater attention in both scholarly awareness of Hindu-Christian encounter and current involvement in direct conversations.

Roland Miller's article on the "trialogue" in Kerala among Hindus, Muslims, and Christians is the only mention in the volume of the Muslim presence in India and its significance for both religious interaction and actual dialogue. His lucid presentation, however, is confined to the very distinctive situation in Kerala, and no one else has commented on the historical significance of Islam for Hindu-Christian encounter or on the contemporary problem that this gap in the book's coverage reveals: the avoidance on the part of so many Christians and Hindus of meaningful dialogue with Muslims. Dr. Miller himself could have taken up these topics, but that would have called for a very different and far more critical essay than the one he was asked to write.

It is one of the ironies of modern Indian history that the conscious Hindu rejection of Islamic cultural as well as political hegemony should have been initiated by a Hindu who was heavily influenced by Islam well before his encounter with Christianity: Rammohun Roy. It is also remarkable how both Hindu and Muslim reform movements in the last two centuries have not only devalued but even "forgotten" various aspects of earlier Hindu-Muslim interaction. What is perhaps more puzzling is that Christians in India have had scarcely more interest in dialogue with Muslims than have Hindus. Clearly the insularity of Muslims has also been an important factor, but each new crisis in Hindu-Muslim relations (most recently in Kashmir) reminds me of a comment made by an Indian Muslim scholar about the absence of Muslim-Christian dialogue: "You Christians know how to conduct dialogue with Muslims," I remember him saying, "but you do not want to. We Indian Muslims want to engage in dialogue, but we do not know how." This is surely a situation in which cultural prejudices and geopolitical realities deeply influence what we like to think of as "pure scholarship" or "pure dialogue!"

The article by A. Frank Thompson outlining the course of Christian views of Hindu bhakti during the past two centuries notes four stages: "an uncomfortable awareness of similarities to Christianity in Indian theism," a confident Christian critique of bhakti religion, the engagement of Rudolf Otto and other Christian scholars with distinctive bhakti doctrines, and "a closer encounter of Christians with Hindu bhakti in the writings of A. J. Appasamy and C. F. Andrews" that "reflect a sense of mutuality between the traditions" (p. 176). Although Dr. Thompson does note the experience of converts as a factor in the developing Christian awareness of similarities, most of his article consists of a useful review of scholarly works in 


\section{Book Reviews}

English. Among the European scholars who have also made a notable contribution is the early twentieth-century German missionary in Tamilnad, H. W. Schomerus. A still more important addition to this topic, however, would be to note the massive contribution of the terminology, symbolism, music, and sensibility of bhakti to Indian Christianity. This is true not only in the more exceptional cases described by Paul Younger in his article, but also in the hymns and prayers of many Christians expressing their religious feelings in their mother tongue. For most of them the bhakti idiom is not a conscious borrowing from another religion but the natural way to express religious feelings. This does not mean, however, that Hindus and Christians can easily share the object of their devotion. While many Hindus and Christians worship at the shrines of different deities, the more serious devotees limit their devotion to a single deity (or divine couple) and their children, attendants, or manifestations. Hindu devotees are accustomed to considering other deities as lower manifestations or exalted servants of one's own Lord, a more generous theoretical position than that of most devotees of "Lord Jesus," but the crucial obstacle to interreligious sharing is the same: the specificity of the object of their "one-pointed" devotion.

Harold Coward has also contributed a chapter to this volume on "The Experience of Scripture in Hinduism and Christianity." At first glance the topic does not seem to fit into any of the four categories I suggested above, but seems to be rather an academic comparison of an important common theme. Dr. Coward's conclusion, however, is entitled, "What Can Each Learn from the Other?" Such learning presumes at least a "long-distance dialogue" and possibly face-to-face conversations as well. The most important and controversial point is the one developed in the final paragraph, that Hindus can learn that

the Christian experience of scripture has traditionally been open and flexible... [and thus] has the capacity to reach out and embrace other scriptures... Awareness of this could help Hindus to see that Christianity is no more exclusivistic than is Hinduism. Each embraces the other by superimposing its own scriptural norms on the other, thereby enabling a limited positive acceptance of the other. Just as Hindus may embrace Jesus Christ as an avatar of Brahman, so Christians may see in Hindu scripture a manifestation of the grace of the Father of Jesus Christ. Neither is a correct perception of the other from its own perspective. But what is achieved is a way of giving positive valuation to the other tradition by an extrapolation and superimposition of one's own scriptural norms. .. Both Christian and Hindu scriptures are exclusivistic (that is, only through Veda or Christ is salvation or release possible). Yet in the heart of each scriptural exclusivism there exists a basis for tolerance and dialogue. (p. 246-47)

Dr. Coward is correct, it seems to me, in seeing that scripture (with its accompanying tradition of interpretation) provides both the opening for and the limits to the flexibility of Christian and Hindu thought. For traditional Hindu as well as traditional Christian thought, "experience" is primarily the personal confirmation of scriptural testimony. To the extent that such experience functions as a supplementary norm, it is not one's own experience, but that of the great saints of the 
past and possibly also of a succession of enlightened teachers extending down to one's own guru. If dialogue is to be true to each religion's own norms, it has to find a way to discuss more than the participants' own experiences in the situation of dialogue. It is the participants' specific "experience of scripture"-in the broad sense that Dr. Coward intends - that both divides them from and unites them to others with a different "experience of scripture." I suspect that this is the case even when there is no conscious intention to understand one another; it is all the more true when there is a conscious effort, however motivated and expressed, at mutual understanding.

On another occasion I should like to develop a supplement to the subject of Dr. Coward's chapter, one that is historically important to the topic of the book. The most important type of "Hindu-Christian dialogue" before the twentieth century, I should like to show, was the conversation between Christian missionary translators and their brahmin consultants in the process of translating the Bible or other Christian texts into the many Indian vernaculars. Rammohun Roy's celebrated dispute with the Serampore Baptist missionaries occurred after a long period in which he had served as a scholar-consultant in the Bible translations, and the dispute itself was occasioned by Roy's distinctive application of the Baptist claim that scripture is its own interpreter.

Robert D. Baird has contributed a chapter entitled "Hindu-Christian Dialogue and the Academic Study of Religion" in which he accepts the first conception of dialogue referred to above in order to distinguish clearly between the academic study of religion, which proceeds "with a spirit of detachment or epoché, logical precision and verbal clarity," (p. 218) and interreligious dialogue, which "presupposes at least two people who meet as equals to advance their experience of God, to come to a more satisfying theological system, or to solve a human problem together. They must be open to the other, and willing to change and appropriate something from the other's experience or ideas" (p. 219). On the basis of Klaus Klostermaier's view that "the real dialogue is an ultimate personal depth" and that dialogue is an end in itself, Dr. Baird concludes that "the very act of dialogue is a religious act and that dialogue itself is a religious experience" (p. 219). With such a restrictive definition of dialogue and with an understanding of the academic study of religion that makes it more restricted than the scholarly study of religion.(p. 222), it is easy for Dr. Baird to maintain that "Hindu-Christian dialogue" and the "academic study of religion" "operate on two different levels (neither higher nor lower)" ( $\mathrm{p}$. 220). "Since 'dialogue in depth' takes place on an interior and spiritual level, it is not methodologically compatible with the academic study of religion" (p. 222).

As we have defined the two terms, it might be quite possible for a single scholar to engage in the academic study of religion as well as to participate in HinduChristian dialogue. But when he or she does so, he or she will be doing two distinct things that cannot be done simultaneously. One simply cannot be detached and engaged simultaneously. (p. 221)

Some of these comments of Dr. Baird's are intended precisely to demonstrate that my attempt to "narrow the gap" between dialogue and academic study is unconvincing, and I therefore hesitate to use this Review for a personal rejoinder. 


\section{Book Reviews}

Since we agree, however in distinguishing academic study from the dialogue of religiously committed people and both use the concept of epoché, meaning suspension of judgment, it may be useful for me to comment briefly on some differences between our approaches. First, I define both dialogue and academic study of religion much more broadly than he does, and I see considerably more overlap, since central to both endeavors is the quest for empathetic understanding of the religious structure embodied in religious persons. I agree that there is a place for suspension of theological (and cultural) judgment, but the indifference of a secular scholar to questions of ultimate truth and value is quite different from van der Leeuw's phenomenological epoché: the temporary suspension of judgment by a religious person quite conscious of what theological and cultural norms he or she is suspending. This self-restraint, moreover, must be combined with the imaginative involvement of the self. For this reason aesthetic sensitivity is as important as logical clarity for the historian and phenomenologist of religion.

It is true that one cannot restrain from and exercise a theological judgment "simultaneously" any more than one can both talk and listen at the same time or in one instant breathe both out and in. My analogies suggest, however, that some contrasting functions are normally and sometimes necessarily connected. The need to present one's own religious position intelligibly is clearly as essential to dialogue as the need for sympathetic listening. To move back and forth is as important as it is difficult, and surely we need to know the difference between rephrasing another's point of view and reinterpreting that viewpoint in the light of one's own. Yet "detachment" and "engagement" are both involved, if not at the same instant, then certainly in the same place, the situation of dialogue, as well as in the same persons.

We who teach in North America have often been apologetic and sometimes embarrassed because of the theological background of the modern academic study of religion, so much so that we seek to exclude witness and interpretation from the legitimate task of the student of religion in the university. For those students of religion for whom the study of religion includes reflection on the meaning of their own faith, such an exclusion is artificial and prevents the scholar from participating in the broader intellectual exchange I am calling "long distance" dialogue.

My further concern about Dr. Baird's sharp distinction is that it seems to me to lend support to those theologians who see no significant role for the historian of religion in inter-religious dialogue. This entire volume is testimony to the value of scholarly efforts to place dialogue in the broader context of inter-religious interaction or encounter. Such historical perspective, along with many other capacities of religiously committed scholars, ought to be a welcome addition to the conference floor for the meeting of Hindus and Christians, in overcoming much misunderstanding and in learning to appreciate one another's faiths, both in their common humanity and in their religious uniqueness. That such scholarly input may add to the complexity of such dialogue is quite possible. Not only are there major differences between Indian and Western notions of "understanding," but the Western philosophical tradition itself has long been split as to whether understanding is possible without acceptance of what is "understood." Certainly all scholars should be aware of the inescapable complexities with which Eric Sharpe concludes: "the 
complexities that need to be taken into account in looking into that most intricate of all subjects - the meeting of person with person, tradition with tradition, faith with faith" (p. 113).

John B. Carman

Center for the Study of World Religions

Harvard Divinity School

Cambridge, Massachusetts

In Seanch of Self in India and Japan: Toward a Cross-Cultural Psychology. Dr. Alan Roland. Princeton, New Jersey: Princeton University Press, 1988, xxxii + 386p.

Roland, a psychoanalyst, compares the extended familial-self typical of Indian and Japanese experience with the individualized self-concept of America. This difference is significant for one's conception of marriage, social relations, art, time and space, subject-object relations and the spiritual goal. Freudian categories (egoideal, superego, etc.) are adopted but contextualized through clinical work with Indian and Japanese patients. Roland demonstrates convincingly that self-concept varies radically according to culture. Therefore, application of Freudian or other Western categories directly to Eastern experience is invalid. Psychological structuring is shown to be embedded in the distinct views of human nature, social patterns and childrearing practices of the various cultures.

This book adds crucial psychological dimensions to our study of Eastern philosophy and religion. It catches the vital nuances of self-experience that escape philosophical and historical approaches. It works well in senior undergraduate and graduate classes and is essential for libraries. The treatment of Japan, however, is weak. The analysis of Indian experience is overly influenced by Vedanta philosophy and shows no sensitivity to the cultural diversity within India. Yet, in spite of these limitations, the book opens important new ground.

Harold Coward

University of Calgary

Calgary, Canada

River of Compassion: A Christian Commentary on the Bhagavad Gìtā. Bede Griffiths. Warwick, N.Y.: Amity House, 1987, 328p., \$11.95.

Another commentary on the Gitta ? There can be little doubt but that in India - both in ancient and in modern times-and in the West-throughout the present century - there has been a literal plethora of bhasyas on this spiritual classic. Arguably the Git $\bar{a}$ is one of, if not the most popular of the religious texts to come from the Hindu tradition. However, as Father Bede rightly points out in his 